\title{
Study on retention of metabolites composition in misai kucing (orthosiphon stamineus) by heat pump assisted solar drying
}

\begin{abstract}
In this research, the effects of different drying methods on the two biomarker compounds concentrations, such as sinensetin (SEN) and rosmarinic acid (RA) of Orthosiphon staminues Benth leaves, flowers, stems and mix were investigated. SEN and RA retention among the dehydrated samples were maximum $83.07 \%$ in leaves and $92.54 \%$ in flowers, respectively by heat pump assisted solar drying method. For heat pump assisted solar dried samples, there are no significant differences $(\mathrm{p}>.05)$ in the retention of SEN and RA as compared to fresh samples. However, there are significant differences $(p<0.05)$ in SEN and RA retention in solar dried leaves, flowers, stems and mix as compared to fresh samples. Besides, an optimization study was performed to evaluate the optimal drying conditions for obtaining high SEN yields from Misai Kucing's leaves, flowers, stems and mixes with high RA contents within the drying parameters.
\end{abstract}

Keyword: Misai kucing (orthosiphon stamineus); Medicinal plants; Antioxidant; Malaysia; Southest Asia 
